\title{
HUBUNGAN PENDIDIKAN DAN PENGETAHUAN IBU DENGAN \\ PEMBERIAN IMUNISASI HEPATITIS B 0 PADA BAYI DI \\ WILAYAH KERJA PUSKESMAS KUALA LEMPUING KOTA BENGKULU
}

\author{
The Relationship between Education And Mother's Knowledge with \\ Immunization Hepatitis $B_{0}$ of Infants in Working Area \\ Kuala Lempuing Public Health Center Bengkulu
}

\author{
Dewi Aprilia Ningsih ${ }^{1}$, Dupriana $^{1}$ \\ ${ }^{1}$ Program Studi DIV Kebidanan STIKES Tri Mandiri Sakti Bengkulu \\ Email : dewiaprilianingsih.i@gmail.com
}

\begin{abstract}
ABSTRAK
Penelitian ini bertujuan untuk mempelajari hubungan pendidikan dan pengetahuan ibu dengan pemberian imunisasi hepatitis $B_{0}$ pada bayi di wilayah kerja Puskesmas Kuala Lempuing Kota Bengkulu. Desain penelitian adalah surveyAnalitik, dengan menggunakan desain penelitian Cross Sectional. Populasi dari penelitian ini adalah semua ibu yang mempunyai bayi lebih dari 7 hari di Puskesmas Kuala Lempuing kota Bengkulu pada tahun 2017 yaitu sebanyak 74 bayi yang sudah imunisasi hepatitis $B_{0}$. Teknik pengambilan sampel dengan teknik menggunakan Sytematic Random Sampling. Pengumpulan data dalam penelitian ini menggunakan data sekunder yang di peroleh dari dokumentasi (register) dan menggunakan data primer yang di peroleh dari Responden (kuesioner) di Puskesmas Kuala Lempuing Kota Bengkulu tahun 2017. Hasil penelitian ini didapatkan (1) Terdapat 34,9\% yang termasuk tingkat pendidikan dasar, 39,5\% yang termasuk pendidikan menengah dan 25,5\% yang termasuk pendidikan tinggi. (2) Terdapat 39,5 yang berpengetahuan kurang, 34,9 yang berpengetahuan cukup dan 25,6\% yang berpengetahuan baik. (3) Terdapat 37,2\% yang tidak melakukan pemberian imunisasi Hepatitis $B_{0}$ pada bayinya dan 62,8\% melakukan pemberian imunisasi Hepatitis Bopada bayinya (4) Ada hubungan yang signifikan antara pendidikan ibu dengan pemberian imunisasi hepatitis $B_{0}$ di Wilayah Kerja Puskesmas Kuala Lempuing Kota Bengkulu dengan kategori hubungan sedang.(5) Ada hubungan yang signifikan antara pendidikan ibu dengan pemberian imunisasi hepatitis $B_{0}$ di Wilayah Kerja Puskesmas Kuala Lempuing Kota Bengkulu dengan kategori hubungan sedang.
\end{abstract}

Kata Kunci : Imunisasi Hepatitis B0, pendidikan, pengetahuan 


\begin{abstract}
This study aims to study the relationship of education and knowledge of mothers with the provision of hepatitis b0 immunization in health center work area of Puskesmas Kuala Lempuing Bengkulu 2017. The research design is an analytical survey, using Cross Sectional research design. The population of this study are all mothers who have babies more than 7 days at Health Center Kuala Lempuing Bengkulu 2017 that is as many as 74 infants who have immunization of hepatitis $B_{0}$. Technique of sampling with technique using Systematics Random Sampling. Data collection in this study used secondary data obtained from documentation (register) and using primary data obtained from Respondents (questionnaires) at Health Center Kuala Lempuing Bengkulu City. The results of this study were obtained (1) There are 34.9\% which includes basic education level, 39.5\% which includes secondary education and 25.5\% including higher education. (2) There are 39.5 who are less knowledgeable, 34.9 are knowledgeable enough and $25.6 \%$ are knowledgeable. (3) There were $37.2 \%$ who did not give Hepatitis $B_{0}$ immunization to their infant and $62.8 \%$ had Hepatitis $B_{0}$ immunization on their infant (4) There was a significant correlation between maternal education and hepatitis BO immunization at Working Area of Kuala Lempuing Health Center of Bengkulu City medium relations category. (5) There is a significant correlation between maternal education with hepatitis $B_{0}$ immunization in Working Area of Kuala Lempuing Health Center of Bengkulu medium relations category.
\end{abstract}

Keywords : Education, hepatitis $B_{0}$ immunization, knowledge

\section{A. Pendahuluan}

Infeksi hepatitis B merupakan penyakit infeksi yang masih menjadi masalah kesehatan yang serius di seluruh dunia, terutama di negara berkembang seperti Indonesia. WHO telah memperkirakan bahwa terdapat lebih dari dua miliar orang terinfeksi virus hepatitis B (VHB) dan 378 juta orang menjadi carrier kronis di seluruh dunia. Diperkirakan 620.000 kematian karena VHB dan 4,5 juta infeksi baru VHB terjadi setiap tahun di seluruh dunia. Menurut WHO, VHB dapat ditemukan di seluruh dunia, tetapi dengan tingkat endemisitas yang bervariasi. Sebagian besar populasi dunia hidup di negara-negara dengan prevalensi HBsAg tinggi $(\geq 8 \%)$ atau intermediet $(2-7 \%)$. Pada daerah tertentu seperti Amerika bagian utara, Eropa bagian utara dan barat, Amerika Selatan, Australia dan Selandia Baru, memiliki prevalensi HBsAg yang relatif rendah $(<2 \%)$ (Aini, 2013).

Indonesia merupakan negara dengan endemisitis tinggi hepatitis B, terbesar kedua di negara South East Asian Region (SEAR) setelah Myanmar. Berdasarkan hasil Riset Kesehatan Dasar (Riskesdas), studi dan uji saring darah donor PMI maka diperkirakan di antara 100 orang Indonesia, 10 diantaranya telah terinfeksi hepatitis B. Sehingga saat ini diperkirakan terdapat 28 juta penduduk Indonesia terinfeksi hepatitis B di antaranya berpotensi untuk menjadi kronis tersebut 1,4 juta orang berpotensi untuk menderita kanker hati (Kemenkes RI, 2014).

Dari data profil kesehatan Kota di Provinsi Bengkulu pada tahun 2015 dari banyak 36.910 bayi, jumlah lahir hidup sebesar 35.824 bayi dan jumlah kematian bayi sebesar 206. Angka kematian bayi $1.000 \mathrm{KH}$ pada enam 
tahun terakhir di Provinsi Bengkulu mengalami naik turun di mana pada tahun tahun 20133,1 per $1000 \mathrm{KH}$, dan pada tahun 2014 kembali naik menjadi 11 per $1000 \mathrm{KH}$ dan tahun 2015 kembali turun cukup signifikan yaitu 6 per $1000 \mathrm{KH}$, jika dibedakan menurut jenis kelamin dengan estimasi, angka kematian bayi laki-laki sedikit lebih besar dari bayi perempuan yaitu 6 per $1000 \mathrm{KH}$ sedangkan bayi perempuan sebesar 5 per $1000 \mathrm{KH}$. (Dinkes Provinsi Bengkulu, 2015).

Penyakit hepatitis B merupakan penyakit menular yang disebabkan oleh virus hepatitis B. Penyakit ini masih merupakan salah satu masalah kesehatan di Indonesia. Prioritas pencegahan terhadap penyakit ini yaitu melalui pemberian imunisasi hepatitis pada bayi dan anak-anak. Hal ini dimaksudkan agar mereka terlindungi dari penularan Penyakit Hepatitis B sedini mungkin dalam hidupnya (Dwi et al, 2011).

Pemberian Imunisasi hepatitis B harus diberikan segera setelah bayi lahir karena imunisasi hepatitis B merupakan upaya pencegahan yang sangat efektif untuk memutuskan rantai penularan penyakit hepatitis B dari ibu kepada bayinya segera setelah lahir. Jadi imunisasi hepatitis $\mathrm{B}_{0}$ diberikan dalam jangka waktu 12 jam setelah bayi dilahirkan. Ini mengingat walaupun hanya 3,9\% ibu hamil yang mengidap penyakit hepatitis B aktif, tetap mempunyai risiko penularan kepada bayinya yang bisa mencapai 90\% (IDAI, 2014).

Pendidikan diperlukan untuk mendapat informasi misalnya hal-hal yang menunjang kesehatan sehingga dapat meningkatkan kualitas hidup. Pendidikan dapat mempengaruhi seseorang termasuk juga perilaku seseorang akan pola hidup terutama dalam memotivasi untuk sikap berperan serta dalam pembangunan. Pada umumnya makin tinggi pendidikan seseorang makin mudah menerima informasi Notoatmodjo dalam Wawan dan Dewi (2011).

Tingkat pendidikan ibu yang rendah mengakibatkan kurangnya pengetahuan ibu dalam menghadapi masalah, terutama dalam pemberian imunisasi, pengetahuan ini diperoleh baik secara formal maupun informal. Sedangkan ibu-ibu yang mempunyai tingkat pendidikan yang lebih tinggi, umumnya terbentuk menerima perubahan atau hal-hal baru guna pemeliharaan kesehatannya.Pendidikan juga akan membuat seseorang terdorong untuk ingin tahu, mancari pengalaman sehingga informasi yang diterima akan menjadi pengetahuan (Pantolawokang, 2016).

Pengetahuan atau kognitif merupakan domain yang sangat penting untuk terbentuknya tindakan seseorang (ovent bahavior). Dari pengalaman dan penelitian ternyata perilaku yang didasari oleh pengetahuan akan lebih langgeng daripada perilaku yang tidak didasari oleh pengetahuan. Ibu dengan pengetahuan kurang, maka akan kurang mendapat informasi dan sulit menerima penyuluhan yang di berikan oleh petugas kesehatan, sedangkan ibu dengan pengetahuan baik akan lebih mudah mendapatkan informasi lebih mudah menerima penyuluhanpenyuluhan yang diberikan oleh petugas Notoatmodjo dalam Wawan dan Dewi (2011).

Berdasarkan data Profil Dinas Kesehatan Kota Bengkulu pada tahun 2015, kelurahan kuala Lempuing adalah kelurahan dimana $\geq 80 \%$ dari jumlah bayi yang ada di desa tersebut mendapat imunisasi hepatitis $\mathrm{B}_{0}$, persentase kelurahan kuala Lempuing di kota Bengkulu tahun 2015 mencapai $82,09 \%$ atau 55 kelurahan dari 67 
kelurahan, cakupan ini menurun jika dibanding tahun 2014 cakupan mencapai $88,1 \%$. Gambaran cakupan kelurahan sebagai berikut : Tahun 2014 yaitu $88,1 \%$, Tahun 2013 yaitu $82,1 \%$, Tahun 2012 yaitu 82,1\%, Tahun 2011 yaitu $74,6 \%$, Tahun 2010 yaitu $82,1 \%$ (Dinkes Kota Bengkulu, 2015).

Berdasarkan data yang di peroleh di Puskesmas Kuala Lempuing di Kota Bengkulu, pada tahun 2014 terdapat 175 bayi yang mendapatkan imunisasi hepatitis $\mathrm{B}_{0}$, sedangkan pada tahun 2015 terdapat 184 bayi yang mendapatkan imunisasi hepatitis $\mathrm{B}_{0}$, sedangkan pada tahun 2016 terdapat 154 bayi yang mendapatkan imunisasi hepatitis $\mathrm{B}_{0}$.

Data Perbandingan yang di peroleh dari Dinkes Kota dmi Kota Bengkulu tahun 2015 ada 2 Puskesmas cakupan imunisasi hepatitis $B_{0}$ yaitu Puskesmas Kampung Bali Kota Bengkulu 185 bayi, dan pada tahun 2016 terdapat195 bayi, sedangkan data yang di peroleh dari Puskesmas Bentiring Kota Bengkulu pada tahun 2015 terdapat 182 bayi, dan pada tahun 2016 terdapat 175bayi yang mendapatkan imunisasi Hepatitis $\mathrm{B}_{0}$.

Berdasarkan hasil dari survey awal yang di lakukan pada bulan Januari-Maret 2017 di Puskesmas Kuala Lempuing Kota Bengkulu, Bayi yang mendapatkan imunisasi hepatitis $\mathrm{B}_{0}$ berjumlah 10 bayi. Dan dari $10 \mathrm{ibu}$ tersebut ditemukan ibu yang berpendidikan SD 5 orang, SMP 3 orang, SMA 2 orang dan 1 orang S1. Dari 10 ibu tersebut 8 orang ibu yang tidak mengetahui imunisasi hepatitis $\mathrm{B}_{0}$ dan tidak mengimunisasikan bayinya dan 4 ibu yang mengetahui tentang imunisasi hepatitis $\quad \mathrm{B}_{0}$ mengimunisasikan bayinya.
Berdasarkan data tersebut, masalah dalam penelitian ini adalah masih rendahnya angka kejadian imunisasi hepatitis $B_{0}$ sehingga tertarik untuk melakukan penelitian lebih lanjut tentang "Hubungan Pendidikan dan Pengetahuan Ibu dengan Waktu Pemberian Imunisasi Hepatitis $\mathrm{B}_{0}$ pada Bayi di Wilayah Kerja Puskesmas Kuala Lempuing di Kota Bengkulu.

\section{B. Metode Penelitian}

Penelitian ini telah dilaksanakan pada tanggal 07 Juni-07 Juli 2017 di Wilayah Kerja Puskesmas Kuala Lempuing di Kota Bengkulu. Jenis penelitian ini adalah survey analitik, dengan menggunakan desain cross sectional. Populasi dalam penelitian ini yaitu seluruh ibu yang mempunyai bayi di atas 7 hari di wilayah kerja Puskesmas Kuala Lempuing di Kota Bengkulu pada bulan Januari-Juni 2017 yaitu sebanyak 74 bayi. Teknik pengambilan sampel yaitu systematic random sampling, dengan jumlah sampel 43 ibu yang mempunyai bayi di atas 7 hari. Jenis data yang digunakan adalah data primer dan data sekunder. Data dianalisis secara analisis univariat dan analisis bivariat. Uji statistik yang digunakan adalah uji chi-square. Untuk mengetahui keeratan hubungannya digunakan uji statistic contingency coefficient $(\mathrm{C})$.

\section{Hasil Penelitian \\ 1. Analisis Univariat}

Analisis univariat digunakan untuk mengetahui gambaran distribusi frekuensi variabel bebas dan variabel terikat. Hasil dari analisis univariat dapat dilihat sebagai berikut : 
Tabel 1

Gambaran Tingkat Pendidikan ibu di Wilayah Kerja Puskesmas

Kuala Lempuing di Kota Bengkulu

\begin{tabular}{clcc}
\hline No & Tingkat Pendidikan & Frekuensi & Persentase $(\%)$ \\
\hline 1 & Dasar & 15 & 34,9 \\
2 & Menengah & 17 & 39,5 \\
3 & Tinggi & 11 & 25,6 \\
& $\quad$ Jumlah & 43 & 100,0 \\
\hline
\end{tabular}

Berdasarkan Tabel 1 dapat pendidikan dasar, 39,5\% yang dilihat bahwa dari 43 orang ibu di termasuk pendidikan menengah dan wilayah kerja Puskesmas Kuala 25,6\% yang termasuk pendidikan Lempuing di Kota Bengkulu terdapat tinggi.

$34,9 \%$ yang termasuk tingkat

Tabel 2

Gambaran Pengetahuan ibu di Wilayah Kerja Puskesmas Kuala Lempuing di Kota Bengkulu

\begin{tabular}{clcc}
\hline No & Pengetahuan Ibu & Frekuensi & Persentase $(\%)$ \\
\hline 1 & Kurang & 17 & 39,5 \\
2 & Cukup & 15 & 34,9 \\
3 & Baik & 11 & 25,6 \\
& Jumlah & 43 & 100,0 \\
\hline
\end{tabular}

Berdasarkan Tabel 2 dapat 39,5\% yang berpengetahuan kurang, dilihat bahwa dari 43 orang ibu di 34,9\% yang berpengetahuan cukup dan wilayah kerja Puskesmas Kuala 25,6\% yang berpengetahuan baik. Lempuing di Kota Bengkulu terdapat

Tabel 3

Gambaran Pemberian Imunisasi Hepatitis $\mathrm{B}_{0}$ di Wilayah Kerja Puskesmas Kuala Lempuing di Kota Bengkulu

\begin{tabular}{cccc}
\hline No & $\begin{array}{c}\text { Pemberian Imunisasi } \\
\text { Hepatitis B }\end{array}$ & Frekuensi & Persentase (\%) \\
\hline 1 & Tidak Imunisasi Hepatitis $\mathrm{B}_{0}$ & 16 & 37,2 \\
2 & Imunisasi Hepatitis B $_{0}$ & 27 & 62,8 \\
& Jumlah & 43 & 100,0 \\
\hline
\end{tabular}

Berdasarkan Tabel 3 dapat dilihat bahwa dari 43 orang ibu di wilayah kerja Puskesmas Kuala Lempuing di Kota Bengkulu terdapat $37,2 \%$ yang tidak melakukan pemberian imunisasi Hepatitis $\mathrm{B}_{0}$ pada bayinya dan $62,8 \%$ melakukan pemberian imunisasi Hepatitis $\mathrm{B}_{0}$ pada bayinya.

\section{Analisis Bivariat}

Analisis bivariat untuk mengetahui hubungan variabel independen (pendidikan dan pengetahuan) dengan variabel dependen (pemberian imunisasi hepatitis $\mathrm{B}_{0}$ ) di Puskesmas Kuala Lempuing Kota Bengkulu. 
Tabel 4

Hubungan Pendidikan Ibu dengan Pemberian Imunisasi Hepatitis

$\mathrm{B}_{0}$ di Wilayah Kerja Puskesmas Kuala Lempuing Kota Bengkulu

\begin{tabular}{|c|c|c|c|c|c|c|c|c|c|}
\hline \multirow{3}{*}{$\begin{array}{c}\text { Pendidikan } \\
\text { Ibu }\end{array}$} & \multicolumn{4}{|c|}{$\begin{array}{c}\text { Imunisasi Hepatitis } \mathrm{B}_{0} \\
\text { pada Bayi }\end{array}$} & & & \multirow{3}{*}{$\chi^{2}$} & \multirow{3}{*}{$\mathrm{p}$} & \multirow{3}{*}{$\mathrm{C}$} \\
\hline & \multicolumn{2}{|c|}{$\begin{array}{c}\text { Tidak } \\
\text { Imunisasi } \\
\text { Hepatitis } \mathrm{B}_{0}\end{array}$} & \multicolumn{2}{|c|}{$\begin{array}{c}\text { Imunisasi } \\
\text { Hepatitis } \mathrm{B}_{0}\end{array}$} & \multicolumn{2}{|c|}{ Total } & & & \\
\hline & $\mathrm{N}$ & $\%$ & $\mathrm{~N}$ & $\%$ & $\mathrm{~N}$ & $\%$ & & & \\
\hline Dasar & 10 & 66,7 & 5 & 33,3 & 15 & 100,0 & & & \\
\hline Menengah & 4 & 23,5 & 13 & 76,5 & 17 & 100,0 & & & \\
\hline Tinggi & 2 & 18,2 & 9 & 81,8 & 11 & 100,0 & 8,631 & 0,013 & 0,409 \\
\hline Jumlah & 16 & 37,2 & 27 & 62,8 & 43 & 100,0 & & & \\
\hline
\end{tabular}

Dari Tabel 4 dapat dilihat tabulasi silang antara pendidikan ibu dengan pemberian imunisasi. Dari 15 orang yang termasuk berpendidikan dasar terdapat 10 orang $(66,7 \%)$ yang tidak memberikan imunisasi hepatitis $\mathrm{B}_{0}$ dan 5 orang $(33,3 \%)$ yang memberikan imunisasi hepatitis $\mathrm{B}_{0}$, dari 17 orang yang termasuk berpendidikan menengah terdapat 4 orang $(23,5 \%)$ yang tidak memberikan imunisasi hepatitis $\mathrm{B}_{0}$ dan 13 orang $(76,5 \%)$ yang memberikan imunisasi hepatitis $\mathrm{B}_{0}$, sedangkan dari 11 orang yang termasuk berpendidikan tinggi terdapat $(18,2 \%)$ yang tidak memberikan imunisasi hepatitis $\mathrm{B}_{0}$ dan 9 orang $(81,8 \%)$ yang memberikan imunisasi hepatitis $\mathrm{B}_{0}$. Hasil uji Pearson Chi-square diperoleh nilai $\chi^{2}$ $=8,637$ dengan $\mathrm{p}=0,013<\alpha=0,05$, jadi signifikan, sehingga Ho ditolak dan Ha diterima, artinya ada hubungan yang signifikan antarapendidikan ibu dengan pemberian imunisasi hepatitis $\mathrm{B}_{0}$ di Wilayah Kerja Puskesmas Kuala Lempuing Kota Bengkulu.

Hasil uji Contingency Coefficient didapat nilai $\mathrm{C}=0,409$ dengan $\mathrm{p}=0,018<\alpha=0,05$ berarti signifikan. Nilai $\mathrm{C}$ tersebut dibandingkan dengan nilai $\mathrm{C}_{\max }=0,707$ (karena nilai terendah dari baris atau kolom adalah 2). Karena nilai $\mathrm{C}=0,409$ tidak jauh dengan nilai $\mathrm{C}_{\max }=0,707$ maka kategori hubungan sedang.

Tabel 5

Hubungan Pengetahuan Ibu dengan Pemberian Imunisasi Hepatitis $\mathrm{B}_{0}$ di Wilayah Kerja Puskesmas Kuala Lempuing Kota Bengkulu Imunisasi Hepatitis $\mathrm{B}_{0}$ pada Bayi

Pengetahuan
Ibu
$\begin{array}{ccc}\text { Tidak } & \text { Tmunisasi } & \text { Total } \\ \text { Imunisasi } & \text { Impatitis } \mathrm{B}_{0} & \\ \text { Hepatitis B } & & \end{array}$ $\chi^{2} \quad \mathrm{p}$ $\mathrm{C}$

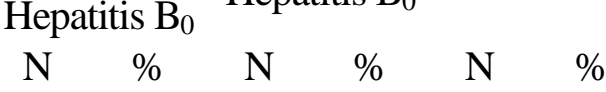

\begin{tabular}{cccccccccc} 
& $\mathrm{N}$ & $\%$ & $\mathrm{~N}$ & $\%$ & $\mathrm{~N}$ & $\%$ & & & \\
\hline Kurang & 12 & 70,6 & 5 & 29,4 & 17 & 100,0 & & & \\
Cukup & 3 & 20,0 & 12 & 80,0 & 15 & 100,0 & 12,845 & 0,002 & 0,498 \\
Baik & 1 & 9,1 & 10 & 90,9 & 11 & 100,0 & & & \\
Jumlah & 16 & 37,2 & 27 & 62,8 & 43 & 100,0 & & & \\
\hline
\end{tabular}


Dari Tabel 5 dapat dilihat tabulasi silang antara pengetahuan ibu dengan pemberian imunisasi. Dari 17 orang yang termasuk berpengetahuan kurang terdapat 12 orang $(70,6 \%)$ yang tidak memberikan imunisasi hepatitis $\mathrm{B}_{0}$ dan 5 orang $(29,4 \%)$ yang memberikan imunisasi hepatitis $\mathrm{B}_{0}$, dari 15 orang yang termasuk berpengetahuan cukup terdapat 3 orang $(20,0 \%)$ yang tidak memberikan imunisasi hepatitis $\mathrm{B}_{0}$ dan 12 orang $(80,0 \%)$ yang memberikan imunisasi hepatitis $\mathrm{B}_{0}$, sedangkan dari 11 orang yang termasuk berpengetahuan baik terdapat 1 orang $(9,1 \%)$ yang tidak memberikan imunisasi hepatitis $\mathrm{B}_{0}$ dan 10 orang $(90,9 \%)$ yang memberikan imunisasi hepatitis $\mathrm{B}_{0}$.

Hasil uji Pearson Chi-square diperoleh nilai $\chi^{2}=13,731$ dengan $\mathrm{p}=$ $0,001<\alpha=0,05$, jadi signifikan, sehingga Ho ditolak dan Ha diterima, artinya ada hubungan yang signifikan antara pendidikan ibu dengan pemberian imunisasi hepatitis $\mathrm{B}_{0}$ di Wilayah Kerja Puskesmas Kuala Lempuing Kota Bengkulu. Hasil uji Contingency Coefficient didapat nilai $\mathrm{C}=0,492$ dengan $\mathrm{p}=0,001<\alpha=0,05$ berarti signifikan. Nilai $\mathrm{C}$ tersebut dibandingkan dengan nilai $\mathrm{C}_{\max }=0,707$ (karena nilai terendah dari baris atau kolom adalah 2). Karena nilai $\mathrm{C}=0,492$ tidak jauh dengan nilai $\mathrm{C}_{\max }=0,707$ maka kategori hubungan sedang.

\section{Pembahasan}

Berdasarkan hasil penelitian menunjukkan ada hubungan yang signifikan antara pendidikan ibu dengan pemberian imunisasi hepatitis $\mathrm{B}_{0}$ di Wilayah Kerja Puskesmas Kuala Lempuing Kota Bengkulu. Hal ini terlihat dari jawaban responden yang berpendidikan dasar sebagian besar $(66,7 \%)$ tidak memberikan imunisasi hepatitis $\mathrm{B}_{0}$ begitupun sebaliknya yang berpendidikan tinggi sebagian besar $(81,8 \%)$ telah memberikan imunisasi hepatitis $\mathrm{B}_{0}$ kepada bayinya.

Hasil penelitian ini sesuai dengan pendapat Notoatmodjo (2012), semakin tingginya tingkat pendidikan seseorangakan semakin mudah menerima informasi sehingga banyak pula pengetahuan yang dimiliki, sebaliknya pendidikan yang kurang akan menghambat perkembangan sikap seseorang terhadap perubahan hidup sehat. Tinggi rendahnya pendidikan seseorang memang mempengaruhi jalannya kehidupan manusia, tetapi keberhasilan manusia dalam hidupnya tidak semata-mata tergantung pada tingkat pendidikan.

Tingkat pendidikan akan sangat berperngaruh terhadap perubahan sikap dan perilaku hidup sehat. Tingkat pendidikan yang lebih tinggi akan memudahkan seseorang atau masyarakat untuk lebih mudah menerima informasi dan mengimplementasikannya dalam perilaku dan gaya hidup sehari-hari, khususnya dalam hal kesehatan. Tingkat pendidikan ibu akan mempengaruhi derajat kesehatan karena ibu dengan pendidikan yang lebih tinggi akan lebih mudah untuk memahami dan menerima sesuatu yang bisa bermanfaat bagi dirinya dan orang disekitarnya, termasuk pemberian imunisasi hepatitis B pada bayinya (Rozalina, 2012).

Menurut Suryani (2011) pendidikan kesehatan adalah suatu proses perubahan perilaku yang bertujuan untuk mempengaruhi sikap, pengetahuan, dan perilaku seseorang, kelompok, maupun masyarakat sehingga tercapai upaya peningkatan kesehatan. Melalui pendidikan kesehatan masyarakat diharapkan mampu memelihara kesehatan mereka, menghindari hal-hal yang merugikan 
kesehatan, dan mampu mencari upaya pengobatan apabila sakit.

Hasil penelitian ini juga menunjukkan bahwa kategori hubungan antara pendidikan ibu dengan pemberian imunisasi hepatitis $\mathrm{B}_{0}$ adalah sedang. Hal ini berarti bahwa pendidikan ibu bukan merupakan satusatunya faktor yang dapat mempengaruhi dalam memberikan imunisasi hepatitis $\mathrm{B}_{0}$, yaitu faktor pengetahuan, lokasi pelayanan kesehatan yang jauh, pekerjaan, dan sikap ibu yang kurang mendukung dalam pemberian imunisasi hepatitis $\mathrm{B}_{0}$.

Hasil penelitian diperoleh dari 15 orang yang berpendidikan dasar terdapat 5 orang $(33,3 \%)$ yang melakukan imunisasi Hepatitis $\mathrm{B}_{0}$ pada bayinya, hal ini dikarenakan adanya faktor lain selain pendidikan yang mempengaruhi ibu untuk memberikan imunisasi hepatitis $\mathrm{B}_{0}$ pada bayinya, yaitu adanya peran aktif kader posyandu yang selalu mengajak ibu untuk mendatangi posyandu maupun puskesmas terdekat untuk memberikan imunisasi serta adanya dukungan dari keluarga khususnya suami kepada ibu agar memberikan imunisasi hepatitis $\mathrm{B}_{0}$ kepada bayi mereka.

Hasil penelitian diperoleh dari 11 orang yang berpendidikan tinggi terdapat 2 orang $(18,2 \%)$ yang tidak melakukan imunisasi Hepatitis $\mathrm{B}_{0}$ pada bayinya, hal ini dikarenakan responden mempunyai riwayat imunisasi sebelumnya anaknya tidak imunisasi sehat dan setelah melakukan imunisasi anaknya meninggal sehingga ibu mengabaikan bayinya untuk mendapatkan imunisasi hepatitis $\mathrm{B}_{0}$, serta terdapat ibu yang keluarga khususnya suami kurang memberikan dukungan agar memberikan imunisasi hepatitis $\mathrm{B}_{0}$ kepada bayi mereka.
Berdasarkan hasil penelitian menunjukkan ada hubungan yang signifikan antara pengetahuan ibu dengan pemberian imunisasi hepatitis $\mathrm{B}_{0}$ di Wilayah Kerja Puskesmas Kuala Lempuing Kota Bengkulu. Hal ini terlihat dari jawaban responden yang berpengetahuan kurang sebagian besar $(70,6 \%)$ tidak memberikan imunisasi hepatitis $\mathrm{B}_{0}$ begitupun sebaliknya yang berpengetahuan baik sebagian besar $(90,9 \%)$ telah memberikan imunisasi hepatitis $\mathrm{B}_{0}$ kepada bayinya.

Hasil penelitian ini sesuai dengan pendapat Hikmawati (2011), mengatakan bahwa bila seseorang ibu memiliki pengetahuan tentang suatu hal maka akan timbul pemikiran tentang segi positif dan negatif mengenai hal tersebut, pengetahuan ini berpengaruh terhadap perilaku seseorang sesuai dengan pemikirannya, kalau positif akan menimbulkan prilaku positif, demikian juga sebaliknya. Dengan demikian pula jika seorang ibu mengetahui manfaat imunisasi hepatitis B pada bayi maka ia akan mengimunisasikan bayinya.

Hasil penelitian ini sejalan dengan penelitian Yuhanadh, 2012) yang menyatakan dimana ada hubungan pengetahuan ibu dengan pemberian imunisasi Hepatitis B 0-7 hari.

Hasil penelitian ini juga menunjukkan bahwa kategori hubungan antara pengetahuan ibu dengan pemberian imunisasi hepatitis $\mathrm{B}_{0}$ adalah sedang. Hal ini berarti bahwa pengetahuan ibu bukan merupakan satu-satunya faktor yang dapat mempengaruhi dalam memberikan imunisasi hepatitis $\mathrm{B}_{0}$, yaitu faktor pendidikan yang rendah, lokasi pelayanan kesehatan yang jauh, pekerjaan, dan sikap ibu yang kurang mendukung dalam pemberian imunisasi hepatitis $\mathrm{B}_{0}$. 
Hasil penelitian diperoleh dari 17 orang yang berpengetahuan kurang terdapat 5 orang $(29,4 \%)$ yang melakukan imunisasi Hepatitis $\mathrm{B}_{0}$ pada bayinya, hal ini menunjukkan bahwa masih ada faktor lain selain pengetahuan yang dapat mempengaruhi ibu untuk memberikan imunisasi hepatitis $\mathrm{B}_{0}$ pada bayinya, yaitu terdapat 2 orang yang selalu diajak oleh kader untuk mendatangi posyandu maupun puskesmas terdekat untuk memberikan imunisasi serta 2 orang ibu yang mendapatkan dukungan dari keluarga khususnya suami kepada ibu agar memberikan imunisasi hepatitis $\mathrm{B}_{0}$ kepada bayi mereka.

Hasil penelitian diperoleh dari 11 orang yang berpengetahuan baik terdapat 1 orang $(9,1 \%)$ yang tidak melakukan imunisasi Hepatitis $\mathrm{B}_{0}$ pada bayinya, hal ini dikarenakan ibu mempunyai pekerjaan sebagai karyawan swasta sehingga kurang memiliki waktu luang untuk sekedar membawa bayinya mendapatkan imunisasi hepatitis $\mathrm{B}_{0}$.

Hasil penelitian menunjukkan bahwa ada hubungan yang signifikan antara pengetahuan ibu dengan pemberian imunisasi hepatitis $\mathrm{B}_{0}$, sehingga pihak Puskesmas Kuala Lempuing perlu berupaya untuk meningkatkan pengetahuan ibu hamil dan ibu yang mempunyai bayi yang berkunjung baik melalui penyebaran leaflet, brosur, pemasangan poster dan spanduk serta memberikan promosi kesehatan mengenai pentingnya hepatitis $\mathrm{B}_{0}$ bagi bayi mereka.

\section{E. Kesimpulan}

1. Dari 43 orang ibu, terdapat 17 orang ibu $(39,5 \%)$ berpendidikan menengah di wilayah kerja Puskesmas Kuala Lempuing Kota Bengkuludengan kategori hubungan sedang
2. Dari 43 orang ibu, terdapat 17 orang ibu $(39,5 \%)$ berpengetahuan kurang di wilayah kerja Puskesmas Kuala Lempuing Kota Bengkuludengan kategori hubungan sedang

3. Dari 43 orang ibu, terdapat 27 orang ibu $(62,8 \%)$ melakukan pemberian imunisasi Hepatitis $\mathrm{B}_{0}$ pada bayinya di wilayah kerja Puskesmas Kuala Lempuing Kota Bengkuludengan kategori hubungan sedang

4. Ada hubungan yang signifikan antarapendidikan ibu dengan pemberian imunisasi hepatitis $\mathrm{B}_{0}$ di wilayah kerja Puskesmas Kuala Lempuing Kota Bengkuludengan kategori hubungan sedang.

5. Ada hubungan yang signifikan antarapendidikan ibu dengan pemberian imunisasi hepatitis $\mathrm{B}_{0}$ di wilayah kerja Puskesmas Kuala Lempuing Kota Bengkuludengan kategori hubungan sedang.

\section{Daftar Pustaka}

Aini. (2013). Faktor Resiko yang Berhubungan dengan Kejadian Hepatitis $B$ pada Pondok Pesantren Putri Ibnul QoyyimYogyakarta. Politeknik Kesehatan Bhakti Setya Indonesia Yogyakarta

Dinkes Provinsi Bengkulu. (2015). Profil Kesehatan Provinsi Bengkulu 2014. Bengkulu

Dwi, M. et al. (2011). Buku Ajar Neonatus, Bayi dan Balita. TIM, Jakarta.

Hikmawati. (2011). Promosi Kesehatan untuk Kebidanan. Yogyakarta : Nuha Medika.

Kemenkes RI. (2014). Profil Kementrian Kesehatan RI 2014. Jakarta : Kemenkes RI.

(2014). Pusat Data dan Informasi Situasi dan Analisis Imunisasi. Jakarta : Kemenkes RI. 
Dwi, M. et al. (2011). Buku Ajar Neonatus, Bayi dan Balita. Jakarta : TIM.

Rozalina (2012). Perilaku Ibu dalam Pemberian Imunisasi Hepatitis B pada Bayi di Wilayah Kerja Puskesmas Sukamara Kabupaten Sukamara Provinsi Kalimantan Tengah. Fakultas Kesehatan Masyarakat Universitas Indonesia. Depok.

Wawan, A \& Dewi, M. (2011). Teori dan Pengukuran Pengetahuan Sikap dan perilaku manusia. Yogyakarta : Nuha Medika.

Yuhanadh. (2012). Hubungan Pengetahuan dan Sikap Ibu dengan Imunisasi Hepatitis $B$ O7 Hari di Wilayah Kerja Puskesmas Panteraja Kabupaten Pidie Jaya. STIKES U'Budiyah Banda Aceh. 